\title{
How histology enriched endodontics as a specialty \& nurtured pulp biology: Our endodontic continuum from 1528 into the 1900's - Part I
}

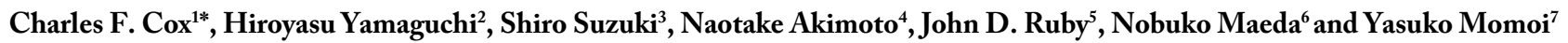 \\ ${ }^{1}$ Visiting Professor, Department of Operative Dentistry, School of Dental Medicine, Tsurumi University, 2-1-3, Tsurumi, Tsurumi-ku, Yokohama 230-8501, Japan \\ ${ }^{2}$ Professor, Department of Research in Dentistry \& Advanced Medical Technology Institute for Research \& Education of Preemptive Medicine, Tsurumi University, \\ 2-1-3, Tsurumi, Tsurumi-ku, Yokohama 230-8501, Japan \\ ${ }^{3}$ Visiting Professor, Department of Clinical \& Community Science, 1919 7th Ave. S. The University of Alabama at Birmingham, AL 35294, USA \\ ${ }^{4}$ Part Time Lecturer, Department of Operative Dentistry, School of Dental Medicine, Tsurumi University, 2-1-3, Tsurumi, Tsurumi-ku, Yokohama 230-8501, \\ Japan \\ ${ }^{5}$ Adjunct Professor, Department of Pediatric Dentistry, School of Dentistry, 1919 7th Ave. S. The Univ. of Alabama at Birmingham, AL 35294, USA \\ ${ }^{6}$ Vice Chancellor, Department of Oral Microbiology, School of Dental Medicine, Tsurumi University 2-1-3, Tsurumi, Tsurumi-ku, Yokohama 230-8501, Japan \\ ${ }^{7}$ Chairperson, Department of Operative Dentistry, School of Dental Medicine, Tsurumi University, 2-1-3, Tsurumi, Tsurumi-ku, Yokohama 230-8501, Japan
}

\begin{abstract}
The 1980 Oral Science Monograph by L.J. Baume of Geneva is an erudite review, which recognized notables who elevated the respect of histology of dentine \& pulp to scientific maturity [1]. Before 1500, "dental surgery" was basically tooth extraction until 1528 when Johannes Stocker recommended treating tooth pain with pulp cautery \& filling some canals with copper. Microscopic observation began in 1675 when Anton van Leeuwenhoek (1632-1723) described transparent pipes from pieces of his wife's tooth using his homemade microscope \& compared tooth enamel \& cementum to tree bark. In 1824, Edward Hudson (1762-1857) of Philadelphia cauterized the tooth pulp \& plugged the canal with gold foil. In 1840, Robert Owen (1804-1892) received recognition by many colleagues for introducing the histologic term DENTINE into our dental lexicon. Histologic knowledge of normal \& pathologic tooth tissues rapidly advanced with microscopic technologies of sectioning \& staining. In 1879, professor Adolph Witzel's (1847-1906) histological study described pulp inflammation \& neo-dentine formations following vital pulp capping of human teeth treated with arsenious acid-he is recognized as the father of histological endodontics [2]. Grossman's 1940 textbook advanced ENDODONTICS as a US clinical specialty by promoting DIFFERENTIAL DIAGNOSIS in patients who were suffering from pulpal or periapical pathology, which led to PROGNOSIS E TREATMENT based on a blend of clinical observations with knowledge of pulp histology. Histological advancements of tooth tissue rapidly advanced the knowledge of normal \& pathological healing, which fostered ENDODONTICS \& RESTORATIVE clinical specialties in the early 1900's. Dr. Wm. Cotton personally backed the PULP BIOLOGY GROUP as a research specialty during the 1975 London IADR meeting. Endodontic tooth treatment rapidly progressed by using new technologies to assist the diagnosis $\&$ treatment of tooth infections.
\end{abstract}

\section{Endodontics emerged as a clinical specialty in the early 1900's, which became strengthened through histological knowledge with pulp biology technologies}

Who were some of the European notables that advanced discoveries from 1860 to 1900 , which became recognized as the classical era of histological innovation? Who published the $1^{\text {st }}$ controlled histologic study that studied the histopathology of an endodontic agent on a human pulp? When was the term endodontia $1^{\text {st }}$ reported to describe the clinical procedure to treat an infected human tooth pulp. Who was the $1^{\text {st }}$ clinician to limit his clinical practice to endodontia? When did the concept of root canal therapy come into accepted treatment of tooth pain? When \& where did the American Dental Association (ADA) \& the American Association of Endodontics (AAE) become organized? When did endodontia-endodontics become a recognized specialty of the ADA? How have recent technological devices advanced the treatment phase of canal instrumentation \& obturation? Who were some of those European colleagues who rapidly advanced the research frontiers of oral biology in the US in the 1940's? When did the PULP BIOLOGY GROUP OF THE IADR become recognized as the organization that defined the standards for the histological testing of vital pulps? As you read through this article, we hope you will learn the answers to these \& other questions.

Correspondence to: Charles F. Cox, DMD, PhD, Department of Operative Dentistry, School of Dental Medicine, Tsurumi University, 2-1-3, Tsurumi, Tsurumi-ku, Yokohama 230-8501, Japan, Tel: (810)-275-8361; Fax: (810)636-4201,E-mail: cfcox@phoenixdental.com

Key words: dentine, endodontics, pulp-biology, therapeutics

Received: June 05, 2017; Accepted: June 21, 2017; Published: June 23, 2017 


\section{From tooth extraction as a quick fix to alleviate a patient's pain - To endodontics as an accepted clinical treatment to remove a painful pulp \& maintain a tooth in function}

Treatment of tooth pain before the 1800's was basically that of extraction [3] except with the exception of a few enterprising individuals who wished to save the tooth by employing innovative clinical procedures. Some would open the pulp to allow drainage $\&$ then cauterize the pulp tissues by rapidly forcing a hot needle into the canal, which they would leave open to drain the inflammatory "mephitic exhalation of fluids" through the access site. A few critical thinking clinicians placed a dry fiber into the canal to prevent impaction of food debris into the access hole. If a gumboil swelling formed after a few days to weeks, some clinicians would place cotton to serve as a "wick" to draw-out the fluids of the connecting gum boil \& wait for the boil to subside rather than extract the tooth. In 1776 Robert Wolfendale travelled to New York from England \& practiced cauterization of the infected pulp with a hot wire without attempting to fill the canal. In some regions of the US in the 1700 's, a clinician would saturate a orangewood peg in phenol \& knock it into the canal by a sudden blow to obliterate the pulp tissue [4].

Studies by John Hunter (1728-1793) in London contributed significantly to the knowledge of dentine morphology \& its slowrhythmic deposition throughout post-eruption. He fed an organic colored food (madder) to pigs \& demonstrated that teeth were not composed of the same tissues as bone-noting that enamel, dentine \& cementum were separate tissues with their own types of vascularization. Hunter observed that the deposition of tertiary dentine in aged vital teeth demonstrated well-defined mineralized madder-colored deposition-lines of dentine, which he characterized as reparative dentine, which theorized that prevented a pulp exposure by creating an internal seal on the pulp interface [5]. Another of Hunter's unique in vivo biological studies was his transplantation of a developing human tooth into the vital tissue of a rooster's highly vascularized chin-comb, which continued to develop with a well-formed root $\&$ then proceeded to eruption through the epithelium of the roosters comb [6].

\section{Fauchard's pulp removal \& filling of the empty canal with gold foil becomes a clinically acceptable treatment}

In 1746, Pierre Fauchard (1678-1761) described the opening of a painful tooth with a hand drill in order to remove the pulp with a barbed needle, after which he placed a piece of cotton saturated with an essential oil e.g. clove or cinnamon to plug the access hole. During that era, some clinicians realized that essential oils had an anodyne effect, however they had no concept about their antimicrobial effects. If the patient's pain persisted, Fauchard replaced the essential oil dressing until the pain subsided, after which he would fill the canal with tin, lead or gold foil to provide closure of the access site to oral debris [7]. Some clinicians throughout major cities of Europe practiced his clinical plugging procedure. In 1757 Etienne Bourdet (1722-1789)-a clinician in Paris limited his procedure to only plugging anterior teeth. In his famous text Chirurgien-dentiste "The Surgeon Dentist" Fauchard described a tooth as consisting of 4-dental tissues-with dentine as the largest tooth component being similar to bone [8]. His text made reference to the microscopic appearance of parallel fibers within the dentine, which may have been his intended description of odontoblastic processes as earlier described by Gabriel-Philippe de la Hire (1677-1719) who is also credited with the discovery of the enamel microstructure of Hunter-Schreger-bands [9].
In the early 1800's of the US, Edward Hudson filled canals with various cements, however many failed due to their solubility \& disintegration, which led to failure \& eventual extraction. Having learned of Fauchard's success with plugging canals with gold foil, Hudson designed his own pluggers to fill the open canals with gold foil, for which he charged his patients a $\$ 10.00$ plugging fee. Following his success, a few clinicians in the larger US cities soon practiced Hudson's gold foil plugging concepts-but there was no mention of treating the instrumented canal with any sort of therapeutic agent [10]. Into the mid 1800 's - a few essential oils had become known to have an anodyne effect against pain, but there were no standardized root canal instruments. Consequently, a few clinicians fashioned their own broaches from jeweler's instruments \& watch springs to create small barbs that enabled removal of pulp tissues.

\section{The era of classical histological discoveries fostered clinical progress in the treatment of pulp inflammation}

The CLASSICAL HISTOLOGICAL ERA is considered as spanning 76-years from 1830 to 1906 . Without any sort of widely available research press during those decades, it is difficult to recognize the individual who named a particular structure or cell, since most ideasharing occurred through handwritten letters between colleagues e.g. Nasmyth (1789-1849), Owen (1804-1892), Harris (1806-1860), Henle (1809-1885), Schwann (1810-1882), Kolliker (1817-1906), Huxley (1825-1895), Czermak (1828-1873), Robert Baume (18481907) throughout academies at Baltimore, Breslau, Berlin, Göttingen, Hamburg, Heidelberg, London, Louvian, Paris, Philadelphia, Stockholm, Vienna, Wurzburg, Zurich [11].

One of the most important leaders \& mentors for young colleagues throughout the CLASSICAL HISTOLOGICAL ERA was Professor Johannes E.K. von Purkinje (1787-1869)-founder of the famous Breslau School of Microscopic Anatomy \& Histology in Prague Czechoslovakia, which ushered in the era of light microscopy (LM) of tissues [12]. One of his personal contributions to the technical advancement of histological technology was the development of a microtome that operated on the principle of squeezing-rather than cutting, as well as collaborating with Lister on the development of a compound achromatic microscope in 1830. Two of Purkinje's famous students (M. Fränkel \& J. Raschkow) of his academy were responsible for the very $1^{\text {st }}$ hand-drawn reproductions of the progressive stages of developing dental tissues with precise tissue detail. Purkinge's students proposed that dentine originated from pulp fibers, which became mineralized \& left continuous canaliculi between them. Raschkow was $1^{\text {st }}$ to demonstrate that the central nerves projected as fine branching fibers to the periphery of the pulp in the vital pulp. In 1865, Waldeyer (1836-1921) formally introduced the term odontoblast into our dental lexicon. Fränkel \& Raschkow's research demonstrated that dentine was formed by odontoblasts of mesenchymal origin, which formed immediately subjacent to the basement membrane, that formed the irregular enamel-dentine junction \& became known as Raschkow's dentine deposition theory \& was supported by T. Huxley $[13,14]$.

London in 1848, Sir John Tomes (1815-1898)-a famous student of professor Thomas Bell (1792-1880)-had become a distinguished prolific researcher \& clinician within his own lifetime, for which he received the honored title of Sir. Tomes is well known for using LM to: 1) describe the minute tubules that projected perpendicularly from the pulp-dentine interface to the EDJ, each with small fibrillar contents that projected from each tubule, leaving a granular layer of tomes in root dentine with occasional fibrils that seemed to connect with cells in 
cementum; 2) he described a protective barrier of secondary dentine as being more coarse \& less tubular than primary/mantle dentine (1848); 3) the intimate \& dynamic relationship of the pulp-dentine interface (1852-1863); 4) he identified peritubular dentine \& the presence of fine nerve processes in certain of the dentine tubules (1863-1868); 5) he defined the concept of ontogeny recapitulating phylogeny [15].

Throughout the 76-years of dental \& medical classical histological advancements, Rudolf A. von Kolliker (1817-1906) $1^{\text {st }}$ of Zurich \& later Würzburg was acknowledged as a principal histologist of the classical LM era publishing 6-editions of his histology textbook between 1852 \& 1903. As a testimonial to his in-depth understanding \& ability to provide detailed hand-drawings, his $1^{\text {st }}$ edition of Human Microscopic anatomy was a comprehensive description of the progressive embryological stages of tooth development to eruption as well as adult tooth histology. He was $1^{\text {st }}$ to recognize that the secretory function of the odontoblasts was a continuous physiological process without any cell modification. He also postulated that through the aging process, certain primary odontoblast cells would die \& pioneer cells would migrate to the pulp periphery \& reorganize themselves as new replacement odontoblastoid cells to form along the pulp-predentine interface to replace the lost odontoblasts [16].

\section{The emergence of american dental education \& re- search, which finally surpassed its formerly recognized mechanical standing}

Chapin Harris (1806-1860) was a founding father of US dentistry \& dental journalism. At 18-years, he studied medicine in the office of his older brother who tutored him in dentistry to become an office partner in 1827 \& passed the Medical Censors Board to begin a medical practice in Greenfield Ohio. In 1835 the State of Maryland Medical \& Chirurgical Faculty board licensed him. As a diligent reader \& book collector-he highly valued art \& scientific literature \& fostered an active correspondence with many of his contemporary colleagues in the US \& abroad. It was said that he had the finest Dental-Medical library in Baltimore at that time.

In 1838, he received an MD degree from Washington Medical College in Baltimore \& was immediately appointed Professor of Dentistry \& published his dental textbook The Dental Art, a Practical Treatise on Dental Surgery in 1839 . His $2^{\text {nd }}$-edition was published as: Principles \& Practice of Dental Surgery \& was edited 11-times with the last edition in 1896 \& yet remains quintessential today.

During 1839, he petitioned the Maryland State legislature to form a College of Dental Surgery \& in 1840 the Baltimore College of Dental Surgery opened as the $1^{\text {st }}$ in the world with a freshman class of 5-students. Dr. Harris served as its $1^{\text {st }}$ dean \& professor of practical dentistry \& became the school's $2^{\text {nd }}$ president in 1844 . In 1840 he founded the worlds first dental journal American Journal of Dental Science, serving as chief editor \& publisher \& remained its editor until his death in 1860. In 1842 he published Diseases of the Maxillary Sinus \& in 1849 he published the Dictionary of Dental Surgery, Biography, Bibliography \& Medical Terminology - the $1^{\text {st }}$ English language Dental Dictionary-the $6^{\text {th }}$ edition appeared in 1898.

Dr. Harris obtained his DDS through membership of the American Society of Dental Surgery (ASDS) - an honorary DDS degree was also conferred to him in 1854 by Philadelphia Dental College. At the 1840 ASDS meeting his motion "resolved that a ASDS be formed" to become reality-serving as its first President \& Secretary in 1844. The ASDS was split in 1856 due to the emotional dental amalgam controversy-
Chapin became a prime organizer of the American Dental Convention (ADC) as the main alternative to the ASDS, serving as the ADC president in 1856-57. In 1859-a year before his death-the ADA was established during a meeting at Niagara-on-the-Lake in New York. Before 1861, most dentists belonged to the ADC or ADA, both of which promoted education \& research in dentistry. During the US Civil war, all Southern US dentists withdrew their ADA memberships \& established their own Southern Dental Association (SDA). After the Civil War, the southern dentists merged with the ADA in 1897 to form the National Dental Association (NDA), which was later renamed the ADA in 1922. In 1839, there were only about 300-trained dentists throughout the US-other operators were quacks or charlatans with little to no training. In 1898 the subscribers list to the ASDS journal was discovered \& published by G.V. Black-being the core group of true professional American dentists to become the leaders of the new US dental profession [17].

\section{G.V. Black's pyramid of knowledge: He grasped basic biological, histological \& pathological concepts \& inte- grated them into his daily clinical treatment procedures}

Green Vardiman Black (1836-1915) had no structured schooling but learned to love reading, learning, philosophy \& logic from his mother \& the knowledge of hand-craftsmanship from his father. He learned that to become well informed in the treatment of the teeth \& oral tissues, it was important to understand histology \& physiology. Upon discharge from the army, GV built a small research laboratory on the $2^{\text {nd }}$ floor above his dental clinic where, after family time each evening, he read Dental Items of Interest \& anything else related to dentistry. GV read the current literature in original German \& French texts of Erlich, Koch, Pasteur, Schwann \& others to learn \& understand the basics of LM tissue preparation of normal oral histology \& pathology. To prepare hard tissues, GV built a sectioning device to cut through mineralized teeth \& jaw tissues for proper fixation, processing, sectioning \& staining of normal \& pathological tissues with a microtome he personally fabricated. GV purchased a commercial microscope \& made his own light source to view glass microslides after daylight faded into darkness. GV spent hours to evaluate his tissue sections \& became an accomplished artist to reproduce precision drawings on the histology \& pathology from tissues he had prepared, which appeared in The Pathology of the Hard Tissues of The Teeth \& Oral Diagnosis. Many of GV's original drawings remained in the $9^{\text {th }}$ edition of Black's Operative Dentistry. GV published his $1^{\text {st }}$ text The Formation of Poisons by Microorganisms in 1884 \& traveled to Germany \& France to deliver lectures on the results of his research-referencing Koch, Miller, Pasteur \& Virchow noting that microörganisms produced waste products that caused disease, caries \& pulp death [18].

GV had a resolute ability to integrate the biological \& morphological science of the tooth with his clinical experience \& practice. His first dental publication was read in 1869 on Gold Foil manufacture, placement \& his concept of cohesiveness. GV's personal research showed that 15 -lbs hand pressure on a 1-millimeter condenser tip was ideal for proper gold foil condensation-he collaborated with M.H. Webb (1844-1883) in the development of an electric foil mallet [19]. GV standardized operative procedures that provided uniformity for Technical Procedures in Making Restorations in the Teeth, which became part of his 1908 Operative text that became used by most dental schools as a standard teaching text. GV was first to invent \& patent the cord-driven dental engine for the clinic \& the gnathodynamometer for measuring bite force. GV wrote about Cavity Nomenclature; Cutting 
Instruments; Adult \& Deciduous Teeth; Control of Pain in Cavity Preparation; Use of the Dental engine; Sharpening Instruments; The Use of Water \& Air; Positions of Operator \& Patient; Keeping the Operating Field Dry; Preparation of Cavities by Classes; Manipulation of Materials for Restoration.

GV was perhaps the first to assemble the scientific puzzle regarding the cause of human caries-having ready access to the literature. His personal LM research \& clinical observations gave him a unique perspective on the existing science of caries of that day, which most others failed to consider. GV pieced together the complex puzzle of human caries from his reading of W.D. Miller's (1853-1907) \& others papers, writing that tooth decay occurred when mouth fluids were habitually acid or alkaline \& that initiation of caries was directly dependent upon lodging of food particles \& plaque in tooth pits \& fissures, followed by fermentation \& acid production that began the demineralization process. GV wrote "what is called fermentation by an organized fermentable agent is but the first step in true fermentation." Until that time, fermentation was mainly a study of the digestive agent $\&$ its waste products (acids) [20].

It is difficult to decide, which of GV's contributions-biological, bacteriological or material sciences-were most important. Although he was born in humble surroundings, he was a self-taught student \& remained so throughout his life. His personal research standards guide many of today's colleagues. GV presented more than 1,300 papers \& lectures over his lifetime-all without governmental research support, computers, Google, face-book or twitter. GV is likely known to most of today's dental students \& colleagues throughout today's world who have read his biological \& clinical contributions, which still have relevance for today's dentists.

\section{From his humble beginnings of a log cabin in the maine wilderness Williams became an accomplished scientist \& clinician to the $1^{\text {st }}$ president of the IADR}

J. Leon Williams (1852-1932) was the major force who guided US dentistry into a science based clinical profession. The Maine dental society owned a microscope for LM, but as none of his colleagues cared about the device he borrowed it for several years. After saving $\$ 100$, he purchased his own microscope \& for the next 7-years he used his microscope for personal research on studying the development of human teeth. He arranged a research lab in his office with a window to the south to catch the daily sun for his microscopes mirror. At age-30 Leon wrote the $1^{\text {st }}$ of his many articles for The Dental Cosmos entitled Studies in the Histo-Genesis of the Teeth and Contiguous Parts, which attracted attention from colleagues around the world, hearing from those who agreed as well as opposed his ideas. In the early 1880's Leon used his LM histological knowledge from his Colby College studies for his personal research on thousands of histological microslides of human teeth. Leon's research was encouraged by W.D. Miller \& by 1882; his research convinced him that caries was the effect of exterior forces on the teeth, realizing that bacteria were directly related to producing caries in a 2 -step process; the $1^{\text {st }}$ step was acid dissolution of the enamel $\& 2^{\text {nd }}$ step was penetration of bacteria into dentine through enamel \& rapidly spreading into the dentine tubule complex. Due to his outstanding histological studies \& understanding of caries, the Baltimore College of Dentistry conferred the DDS degree to him in 1883. The Royal Anthropological Institute of Great Britain \& Ireland honored him as a Fellow In 1913. Perhaps his most notable honor was as the $1^{\text {st }}$ elected president of the International Association For Dental
Research (IADR), in recognition for his many different contributions for which the entire dental profession has benefited. Dr. Williams served on the IADR editorial board until 1931 [21].

Dr. Alfred E. Gysi (1865-1957) was born in Aareu Switzerland \& showed strong scholarship as a young lad. At 16, he began dental studies in Geneva Switzerland \& completed his DDS at Pennsylvania Dental College in 1884 \& his PhD in 1887 . He returned to Zurich to complete his Federal Dentistry Diploma in 1889 \& became co-founder of The Zurich Dental Institute \& Professor of Prosthetics at Zurich in 1931. Dr. Gysi was the only dentist to receive the oldest Swiss Science Marcel Benoist Award in 1925 for his scientific contributions. Noted worldwide academics \& clinicians held Dr. Gysi in highest esteem for his multidimensional contributions \& depth of clinical insight.

Dr. Gysi validated John Neill's (1819-1880) 1842 theory of dentine fluid dynamics in the dentine tubules by correctly defining the mechanism of human tooth sensitivity from his clinical observations of fluid movement along cavity walls during restorative procedures [22]. Stirred by Dr. Neill's 1842 thesis, Gysi published his thoughts on the fluid theory of dentine sensitivity in 1899 , which was later confirmed by the scientific research of Dr. Martin Brännström (1922-2001) in 1968 $[23,24]$. Some colleagues believed dentine sensitivity was due to the presence of nerves in human dentinal tubules that responded to various stimuli, while others accepted that dentine sensitivity theory was due to the odontoblast process extending the length of the dentinal tubule complex, which registered the initial sensory stimuli \& conveyed it to the sub-odontoblastic nerve plexus $\&$ the brain as pain. Alfred wrote in his daily clinical diary, that during gentle removal of the outer infected soft carious dentine-before local anesthesia \& electric dental engines were commonplace-he would periodically stop to provide the patient momentary relief from the drilling. After returning to the cavity, he observed fluid on the cavity floor \& during its removal with a small dry wick, some patients complained of a sharp painful reaction-gaining relief when he rapidly removed the moist wick. From his clinical observations, he realized that the rapid drying of fluid from the dentine cavity floor \& walls supported Neill's 1842 theory of fluid dynamics in vital dentine. Dr. Gysi published his erudite article An attempt to explain the sensitiveness of dentine in the 1900 Brit Jour of Dent Res, which considered fluid flow in the dentinal tubule complex-69-years before Dr. Brännström's hydrodynamic theory of human dentine sensitivity [25]. While a professor at Zurich in 1894, Gysi constructed his own microphotographic camera, which used lamps for nightlong exposures to produce the $1^{\text {st }}$ published photomicrographs of the developing human enamel-dentine-pulp interface.

In the US an active group of young LM histologists was led by Dr. Carl Heitzman-originally from Vienna-began a biological school of dental medicine in New York. One of his most notable students was C.F. Bödecker (1895-1965) who wrote the $1^{\text {st }}$ American text of dental anatomy \& pathology based his LM histological studies that demonstrated dentinogenesis from the embryonic stages into aged tooth development. In $1879 \& 1882$, Bödecker was $1^{\text {st }}$ to accurately describe the pattern of sequential mineralization of human dentine [26]. In addition to defining histological demineralization, processing, celloidine embedding, sectioning \& staining, he used oil-immersion to clarify his observation of the fine spindle-shaped fibers that were present between odontoblasts during their initial deposition of dentine-these fibers are now called von Korff fibers \& have been demonstrated in the initial matrix deposition of new dentine bridge deposition by the newly formed pioneer odontoblastoid cells of mesenchymal origin [27]. 
The american era of dental research comes of age during the 1940's with the migration of oral biology colleagues from Vienna Austria

In 1926, Dr. William J. Gies submitted a detailed report to The Carnegie Foundation on the status \& needs of teaching \& research advancements of dental education in the US. His report recognized the need for improving the development of oral biology research within the dental institutions \& to integrate their biological aspects into US dental school curricula [28]. This report was most timely, as US dentistry had finally moved beyond its previous recognized status as nothing other than a technical trade that made oral prosthesis. By 1943 some US schools that allied with major university medical schools had become recognized as an equal profession to that of medicine. With the establishment of the Baltimore Dental College in 1840, most US dental schools had become noted for the teaching of exodontia with technological fabrication of removable prosthetics \& fixed gold restorations, however only with minimal emphasis on biological concepts.

Dr. W.H.G. Logan (1872-1943) the Dean of Loyola Dental \& President of the 1925 FDI Congress in Geneva reached out to Dr. Bernhard Gottlieb (1885-1950) who was the Director of the Dental Institute at the University of Vienna Austria. Gottlieb continued the academic legacy of histology, oral biology \& pathology that began in 1898 under the leadership of Dr. Julius Scheff (1846-1922). Dr. Logan invited Dr. Gottlieb \& several of his associates to Loyola in Chicago Ill following the 1926 International Dental Congress in Philadelphia. Throughout the 1920's to 1930's, Drs. Gottlieb \& Baliant Orban (1889-1960) had published many detailed histological features of pulp, cementum \& periodontal tissues of developing \& adult tissues of human teeth [29]. At the invitation of Dr. Logan of Loyola Dental in Chicago, Dr. Orban joined the Loyola faculty with Dr. L.B. Fink who had a well-equipped research laboratory. Together, they organized research courses in oral histology \& pathology for the 20-faculty members. Dr. Orban published his textbook DENTAL HISTOLOGY AND EMBRYOLOGY in 1928 with the assistance of recognized colleagues, which became the textbook of choice by most dental schools throughout the English-speaking world [30]. During his 2-years at Loyola, Dr. Orban published over 20-research papers \& presented over 30 -lectures but he elected to return to Vienna to resume his research efforts.

In 1930, Loyola Dental in Chicago appointed Dr. Rudolf Kronfeld (1901-1940)—a brilliant protégé of Dr. Gottlieb—as its $2^{\text {nd }}$ director. By 1933, Dr. Kronfeld had completed clinical requirements for his DDS, as well as publishing a textbook Histopathology of the teeth and their surrounding structures, a testimonial to his energetic \& brilliant rise to international recognition \& expertise in oral biology research \& teaching [31]. The academic pathway by which Kronfeld had firmly established himself as an oral biology researcher \& then gained his DDS, which provided him a unique clinical pathway with a very unique perspective of the interrelationship of carrying out laboratory research $\&$ its integration with clinical practice. In 1935, the CEO of Pepsodent corporation made a 10 -year annual gift of $\$ 25,000$ to Loyola Dental School to support the dental research of Dr. Kronfeld \& his colleagues. "Kronfeld recognized and clearly articulated to his fellow clinicians the critical relevance of good research to the standing of dental practice in the community [32].” In 1939, Kronfeld was diagnosed with a fatal neurological disease \& died in his laboratory at the age of 39.

\section{The era of transmission electron ultramicroscopy (TEM) arrived in 1948 when Dr. Bernick was $1^{\text {st }}$ to de- scribe normal ultrastructure of tooth tissues as well as the nature of caries \& its invasion into the tooth tissues}

By 1949, Pease \& Baker had developed predictable TEM ultrastructural histological procedures for the fixation, embedding \& ultrathin sectioning of tissues at $0.5 \mu \mathrm{m}$ or less [33] - until then the replica technique was the only practical means to enable a limited study of mineralized tooth tissues [34].

The $1^{\text {st }}$ ultrastructural TEM studies of tooth tissues were published by Dr. Sol Bernick (1915-1989) in 1952. Sol was born in St. Paul MN \& studied anatomy \& pathology where he received his BS degree from the Univ. of Minnesota. After serving in the U.S. Navy, Sol spent time at the Armed Forces Institute of Pathology in Washington DC, \& then settled in Los Angeles to join Dr. L. Bavetta at USC Dental School where he completed his $\mathrm{PhD} \&$ was appointed as instructor in histologybecoming Professor in 1965 . He published his $1^{\text {st }}$ paper in the JDR in 1942 \& 9-more by 1949 becoming recognized for research on the LM innervation of teeth \& various oral structures; on the inflammatory reaction; on tumorigenesis; on the embryonic formation of teeth \& associated structures \& lymphatic's, in which he became recognized as an international authority on oral histology research. Sol co-authored an Oral Histology \& Embryology textbook with James K. Avery \& was instrumental in writing several chapters in more than 10-books. It was at Mich. where Dr. Cox $1^{\text {st }}$ met Dr. Bernick in 1968. For many years, he spent several weeks of the summer in our oral histology research laboratory-always with a cigar in his mouth over containers of alcohol \& xylene-where my colleagues \& I learned the "Bernick" method for celloidin, paraffin light histology \& more importantly for myself \& his knowledgeable finer merits of TEM ultrastructural preparation \& histological evaluation [35]. His 1952 TEM publications: Electron Microscopy of Enamel \& Dentin in the JADA \& the 1954 Electron Microscopy of Carious Dentin in the JDR were the $1^{\text {st }}$ studies to describe the normal \& pathological ultrastructural changes that occurred in carious dentine, which had not been previously demonstrated by LM histology. His $0.5 \mu \mathrm{m}$ ultrathin sections showed 4-zones of degeneration based on the degree of microbial invasion. It was not only papers that he published, but he was also instrumental in writing several chapters in more than 10-books. Dr. Bernick was the $1^{\text {st }}$ to employ TEM to differentiate 4-zones of degeneration in the caries lesion. The outermost zone was called the superficial infected carious zone of non-vital dead dentine-seen as a soft crumbly mass with millions of coccid \& rods shaped microörganisms. The $2^{\text {nd }}$ deeper zone is an incipient layer that is just beginning to show HAp demineralization, in which the peritubular wall is destroyed with disruption of any normal tubule morphology. The pioneer microörganisms are strep \& LBA, however the collagen remains unaltered, which provides a substrate for possible remineralization into a future zone of dense sclerotic dentine. Sol showed by TEM, that the $3^{\text {rd }}$ deeper zone is filled with small transparent refractory nano-crystals \& is considered as a self-healing zone of remineralization, in which the tooth produces on its own. The deepest $4^{\text {th }}$ zone is very thin, being situated quite far ahead of any actual demineralization of the peritubular dentine-where only a few pioneer microörganisms may be located $[36,37]$. 


\section{The clinical evolution of root canal therapy from pulp removal \& plugging with gold foil to the introduction of therapeutic agents to eliminate microörganisms}

From the early 1800 's to the 1860 's root canal treatment was generally confined to the removal of the exposed pulp tissues with barbed instruments $\&$ then just left open to drain any fluids. By 1873 the research of A. Wetzel \& others had begun to understand that the presence of bacteria in the dentine tubules as well along the crevices \& walls of infected pulp canals were responsible for continuing infection \& periapical inflammation. From these observations, Wetzel realized that following the removal of an infected pulp tissue, that it was important to provide a septic phase of therapeutic canal treatment to kill those bacteria that remained following tissue removal. $\mathrm{He}$ introduced the use of phenol (carbolic acid) as a therapeutic agent to treat the instrumented root canal surfaces. Witzel's histological research studies of the 1870's compared vital pulp capping when contrasted to placement of arsenious acid on infected canals \& established the $1^{\text {st }}$ scientific evaluation of endodontic procedures, for which he is known as the father of histological endodontic research. In 1876 Dr. N.C. Keep of Boston MA introduced the placing of a mix of zinc-oxychloride cement to fill instrumented root canals \& for direct pulp capping of vital pulps [38].

\section{Endodontics becomes a clinical reality $\&$ develops as a recognized ADA specialty}

With advances in the knowledge of pulp histology by the 1900's some clinicians in the US-instead of just extracting a painful toothattempted to treat \& maintain an infected tooth as a functioning part of the human dentition for the patient. By that time, root canal treatment in the US was being attempted by some clinicians \& was referred to as pathodontia. By 1928 Dr. H.B. Johnson of Atlanta GA was acknowledged to be the $1^{\text {st }}$ clinician to limit his practice to endodontics-a term he defined by merging 2-words en from Greek

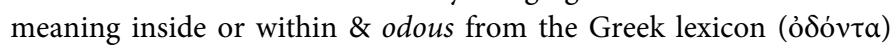
referring to the tooth [39].

The clinical treatment of inflamed \& infected pulps became accepted as an endodontic specialty in 1943 when a group of US clinicians met in Chicago to organize the AAE. In the $1^{\text {st }}$ issue of the AAE journal, Dr. Baliant Orban discussed the need for pursuit of science \& clinical treatment for endodontics to be recognized as a clinical specialty. Drs. W.C. Davis, J.H. Hospers \& L.I Grossman called for 19-colleagues to meet at the Palmer House in Chicago to formally organize endodontics as a clinical society. By 1963, over 200-US clinicians had limited their dental practice to endodontics \& the ADA officially recognized endodontics as a clinical specialty in 1965 [40].

\section{The use of natural plants \& minerals, which led to the pharmacological rational that promoted the therapeu- tic phase of endodontic treatment}

Aristotle (384-322BC) from nearby Thessaloniki Greece, credited Hippocrates (460-370BC)-from Kos in northern Greece-as the Father of Medicine who taught his student to move beyond the ancient consideration of unnatural or supernatural myths of disease by teaching that critically thinking people should employ independence of thought in all of their actions as well as teaching \& practice in their treatment of infirmities \& pain control of diseases [41].
Paracelsus (1493-1541) the Swiss physician studied medicine at Basel University at age of 16-years \& gained his doctorate at Farrara University in 1516 . He is considered the founder of toxicology who proposed the use of rational therapeutics \& was one of the $1^{\text {st }}$ individuals to report that plants contained natural agents, which promoted therapeutic values. He regarded that superstitions were ridiculous tales that had no ability to promote healing of diseases [42].

In 1865, Dr. Claude Bernard (1813-1878) of France published his textbook An Introduction to the Study of Experimental Medicine [43]. He introduced experimental medicine \& the study of disease in the living human body. He studied the role of the pancreas in the digestion process of fats \& sugar on the blood \& he also demonstrated the pharmacological action of many drugs on the human body \& made it acceptable to visualize tissue reactions to drugs rather than by just accepting previous statements that had been based only on clinical observations without any sort of long-term studies with scientific evidence to validate the mechanisms of action.

\section{Therapeutic principles for the treatment of vital \& non- vital teeth}

The 1950 Endodontia textbook by Edgar A. Coolidge is an early classic academic clinical text with chapters that cover tooth pain, clinical treatment of hypersensitive dentine, treatment of infected \& pulpless teeth, the maintenance of pulp vitality \& removal of pulps in preparation for filling-the clinical information remains absolutely relevant for students \& clinicians even today. The Coolidge's text is a must read for any endodontic graduates who wish to learn something of the notables who encouraged the emergence of endodontics as a dental specialty \& contributed through the early 1900's as well as those clinicians who practice conservative pulp treatment. His comprehensive Endodontia text clarified clinical procedures for caries removal, temporary caries control with indirect placement of anodyne agents to alleviate patient pain as well as provide germicidal control of microörganisms using sulfonamides \& antibiotics. Those early decades of the 1900's clarified diagnosis \& root canal instrumentation, which served to usher in the therapeutic age of endodontics [44].

The classic 1929 publication by Dr. E. Coolidge revitalized---\& brought back to the forefront, the important 1894 publication of Dr. W.D. Miller who was the $1^{\text {st }}$ to report streptococci, staphylococci of albus \& aureus, bacilli \& other micrococci forms in various carious \& pulpal lesions. Studies by Jordan, Prinz, Appleton \& others demonstrated that different strains of strep viridens \& hemolytic types, pneumococci as well as gram positive \& negative forms, which are aerobic, microaerophilic $\&$ anaerobic have been observed in infected pulps [45-48].

Dr. Coolidge, the Emeritus Professor at Chicago College of Dentistry at Loyola University text identified a number of clinical steps, by which each clinician should follow before attempting final filling of the instrumented canal. For those teeth with vital pulps: 1) establish an aseptic field. 2) control the patient's pain. 3) gain workable canal access. 4) remove all necrotic pulp tissue. 5) use a culture test to prove sterility. 6) fill to the pulp stump. 7) maintain periapical tissues. For nonvital pulpless teeth: 1) control the infection. 2) gain workable access. 3) thoroughly clean the canal. 4) disinfect the dentine. 5) control periapical sterility. 6) provide an apical seal. 7) prevent reinfection. 8) restore \& maintain the periapical [bacteriometic] seal [49].

Dr. Coolidge wrote that an effective germicide needed to be strong enough to destroy the microörganisms without damaging the vital 
pulp stump or subjacent periapical tissues, or causing patient pain or discoloration of the tooth dentine [50]. Several of the early germicides were acids, metallic salts, zinc chloride, silver nitrate, formalin, alcohol \& phenol were recognized canal germicides that coagulated albumen or were self-limiting due to limited penetration. Research by Feirer \& Leonard demonstrated that it was important that therapeutic agents of low-surface tension would allow penetration into the irregular crevices \& accessory canals otherwise their intended purpose would be limited or totally non-effective [51].

In his 1891 article, Dr. O. Walkoff of Leipzig recommended the use of camphorated monochlorophenol (CMCP) - an agent whose chemistry acted by the manner in which several hydrogen atoms of the CMCP are replaced by chlorine, which renders it effective. The final agent is more germicidal than phenol in that it penetrates into the accessory canals \& irregular instrumentation irregularities \& does not coagulate albumin or cauterize vital tissues. However, to be effective in root canal treatment, the CMCP needs to be placed as a moistened paper point \& sealed into the canal for the time between appointments. Consequently, CMCP never became popular with most clinicians due to its multiple patient visits, which required additional filing of the canal walls \& definition of the canal apex-periapical interface [52].

In 1917, Dakin \& Dunham reported on the efficacy of a mixture of calcium hypochlorite \& calcium chloride \& buffered with the addition of boric acid to balance the solution to a $0.5 \%$ strength that kept it useful for 1-week without decomposition. The benefit of this agent was its rapidity of killing microorganisms with a solvent action on necrotic tissue \& little to any injury to the vital tissues [53-55]. During the years after WW-I, other modifications of chlorine e.g. Chloramine-T \& Dichloramine were developed, but they were found to be less effective than the Dakin solution.

This Part I document has attempted to highlight the efforts of those many notable histological researchers from previous centuries \& to identify some of those enterprising clinicians who contributed to the inception of a healing specialty, which provides relief from pain \& inflammation that provides an alternative to tooth extraction. It is our aim that Part II will provide a more comprehensive review of colleagues, technologies \& pulp biology research (Table 1), which has advanced our endodontic specialty in the last century.

\section{Acknowledgements}

Each author owes an especial note of gratitude to those faculty, colleagues, family \& friends who have supported each of us throughout our formative research \& academic years \& have given their personal time $\&$ individual kindness, in which they continued to encourage us throughout our careers.

Table 1. Noted events in histology, endodontics \& pulp biologyresearch from 1528 into the 1950's.

\begin{tabular}{|c|c|c|}
\hline Dentist / Clinician & Dates \& Age & Observation \\
\hline Aristotle & 384-322BC & A famous Greek philosopher, scientist \& mathematician as well as an affectinado of Hippocrates [41]. \\
\hline Johannes Stocker & 1528 & Recommended treating tooth pain by cauterizing the painful tooth cavity \& pulp with a hot device [1]. \\
\hline Dr. Petrus Monau & circa 1551-1599 & $\begin{array}{l}\text { Published the } 1^{\text {st }} \text { doctoral dissertation at Basel, Switzerland in } 1578 \text { on the biology \& pathology of teeth } \\
\text { \&considered that the teeth were like bone. }\end{array}$ \\
\hline Dr. TobusDornkreilius & 1601 & Advanced the concept of cauterizing an infected pulp \& plugging the open canal with copper amalgam [1]. \\
\hline Antonvan Leuwenhoek & $1632-1723$ & $\begin{array}{l}\text { Inventor of the microscope } \& \text { observed transparent pipes } \& \text { tubes in pieces from his wife's tooth with a } \\
\text { microscope that he fabricated.He likened enamel \& cementum to tree bark. }\end{array}$ \\
\hline Dr. Pierre Fauchard & circa $1678-1761$ & $\begin{array}{l}\text { A French clinician who practiced opening of a painful tooth to remove the pulp with a barbed device } \& \text { then } \\
\text { placed a cotton plug saturated with an essential oil [8]. }\end{array}$ \\
\hline Dr. Philippe de la Hire & $1677-1719$ & A famous notable of France who described the nature \& formation of the enamel-dentine junction [9]. \\
\hline Dr. Etienne Bourdet & $1722-1789$ & $\begin{array}{l}\text { A famous Parisian dentist who only treated anterior teeth \& plugged them with a cotton plug saturated an } \\
\text { essential oil \& closed the access with gold foil. }\end{array}$ \\
\hline Dr. John Hunter & $1728-1793$ & $\begin{array}{l}\text { A noted London researcher who demonstrated the slow rhythmic deposition of dentine in pig teeth.He } \\
\text { transplanted a developing human tooth into a rooster comb that continued to develop \& erupt }[5,6] \text {. }\end{array}$ \\
\hline $\begin{array}{l}\text { Dr. Edward } \\
\text { Hudson }\end{array}$ & $1762-1857$ & $\begin{array}{l}\text { Living in Philadelphia PA he removed the tooth pulp with a broach \& attempted to fill with a cement, which } \\
\text { often failed so he plugged the canal with eithertin, lead or gold foilfor a } \$ 10.00 \text { clinical fee in } 1824[10] \text {. }\end{array}$ \\
\hline Dr. Robert Wolfendale & circa 1776 & $\begin{array}{l}\text { Immigrated to New York from England \& practiced cauterization of the infected pulp with a hot wire, but } \\
\text { made no attempt to fill the canal. }\end{array}$ \\
\hline $\begin{array}{l}\text { Professor Evangelista } \\
\text { K. von } \\
\text { Purkinje }\end{array}$ & $1787-1869$ & $\begin{array}{l}\text { A founder of the famous Breaslau School of Microscopic Anatomy \& researcher who ushered in the } 70 \text {-year } \\
\text { Classical Era of Histology that advanced the knowledge of the human oral biology [12]. }\end{array}$ \\
\hline Dr. Robert Owen & 1804-1892 & $\begin{array}{l}\text { A clinician \& histologist from the Royal College in London who formally introduced the term DENTINE } \\
\text { into our dental lexicon [1]. }\end{array}$ \\
\hline Dr. Chapin A. Harris & $1806-1860$ & $\begin{array}{l}\text { A founding father of US dentistry \& advocated for dentistry as a medical-based structured profession. } \\
\text { He was a co-founderwith Dr. Hudson of the } 1^{\text {st }} \text { US dental school in } 1839 \text { at Baltimore. He cautioned that } \\
\text { charlatans misused amalgam. His } 1849 \text { text recommended replacing lead with crystalline gold \& rolled gold } \\
\text { pellets. [17]. }\end{array}$ \\
\hline Dr. Claude Bernard & $1813-1878$ & $\begin{array}{l}\text { A famous French notable who published a famous text ODONTOGRAPHY as well as AN INTRODUCTION } \\
\text { TO THE STUDY OF EXPERIMENTAL MEDICINE[43]. }\end{array}$ \\
\hline \begin{tabular}{|l|l|l} 
Sir John \\
Tomes
\end{tabular} & $1815-1895$ & $\begin{array}{l}\text { A famous notable London clinician \& histologist who made many great contributions to the understanding } \\
\text { of tooth histology \& morphology [15]. }\end{array}$ \\
\hline $\begin{array}{l}\text { Dr. Rudolff A } \\
\text { von Kölliker }\end{array}$ & $1817-1906$ & $\begin{array}{l}\text { A famous notable from Würzburg of the CLASSICAL HISTOLOGICAL ERA who was } 1^{\text {st }} \text { to report the } \\
\text { secretory function of the odontoblast \& also published his works in 6-editions of HUMAN MICROSCOPIC } \\
\text { ANATOMY(16). }\end{array}$ \\
\hline Dr. John Neill & $1819-1880$ & $\begin{array}{l}\text { The } 1^{\text {st }} \text { to report on the nature of fluid in the dentine tubules to the cause of dentine sensitivity of human } \\
\text { teeth [22]. }\end{array}$ \\
\hline Dr. Meyerus Frankel & circa $1820-1870$ & $\begin{array}{l}\text { A famous student of Purkinje at Breaslau who drew \& first described the stages of human tooth development } \\
\text { from his microscopic slides [13]. }\end{array}$ \\
\hline
\end{tabular}




\begin{tabular}{|c|c|c|}
\hline $\begin{array}{l}\text { Dr. Isaacus } \\
\text { Raschkow }\end{array}$ & circa1820-1870 & $\begin{array}{l}\text { A famous student of Purkinje at Breaslau who demonstrated the mesenchyme origin of primary odontoblasts } \\
\text { in the human tooth [14]. }\end{array}$ \\
\hline Dr. E. Magitot & $1833-1897$ & $\begin{array}{l}\text { A noted researcher from Paris who defined the vascularization of teeth buds \& the genesis of the secondary } \\
\text { dentine formation in } 1858 \text {. }\end{array}$ \\
\hline Dr. Greene Vardiman Black & $1836-1915$ & $\begin{array}{l}\text { The Father of American Dentistry who provided insight \& understanding on caries due to bacterial infection } \\
\text { as well as to clarifying the science \& carried out his own laboratory research to define clinical standards for } \\
\text { operative cavity preparation, amalgam composition, trituration \& amalgam placement into well defined \& } \\
\text { instrumented cavities [18-20]. }\end{array}$ \\
\hline Dr. W. Waldeyer & Circa 1835-1888 & $\begin{array}{l}\text { A famous researcher from Breslau who was noted for his bone research \&was } 1^{\text {st }} \text { to add the term odontoblast } \\
\text { to our dental lexicon in } 1865 \text {. }\end{array}$ \\
\hline Dr. N. C. Keep & circa 1840-1895 & $\begin{array}{l}\text { A clinician of Boston MA, he introduced the placement of a zinc-oxychloride as a pulp capping agent \&also } \\
\text { plugged it into an instrumented pulp canal.In } 1876 \text { as a filling agent to stabilize the root structure [38]. }\end{array}$ \\
\hline Dr. Marshall Hickman Webb & $1844-1884$ & $\begin{array}{l}\text { A recognized biological researcher as well as a noted US gold foil clinician who improved an electro- } \\
\text { mallet for the condensing of cohesive gold foil into well defined \& designed cavity preparations. Wrote the } \\
\text { Restoration of Contour and Prevention of Extension of Decay. }\end{array}$ \\
\hline Sir - Dr. Charles S. Tomes & $1846-1928$ & $\begin{array}{l}1^{\text {st }} \text { acknowledged amalgam study evaluated } 8 \text {-amalgam formulations \& observed that } 7 \text {-silver amalgams } \\
\text { leaked, while the copper amalgam failed to show any shrinkage or microleakage [1]. }\end{array}$ \\
\hline Professor Adolph Witzel & $1847-1906$ & $\begin{array}{l}\text { Clinician who carried out the } 1^{\text {st }} \text { histologic pulp biology research study of placing arsenious acid onto vital } \\
\text { human pulps. Considered the FATHER OF HISTOLOGICAL ENDODONTICS[2]. }\end{array}$ \\
\hline Dr. John Leon Williams & $1852-1932$ & $\begin{array}{l}\text { A major notable of US dentistry who was a histologist as well as famous clinician who also contributed to the } \\
\text { understanding of caries Leon contributed research studies on the cause of human caries from external plaque } \\
\& \text { microorganisms that invaded enamel \& dentine. He was the } 1^{\text {st }} \text { president of the IADR [21]. }\end{array}$ \\
\hline Dr. Otto Walkoff & circa 1863 & $\begin{array}{l}\text { A clinician from Berlin who placed paper points saturated with CMCP into root canals as a therapeutic agent } \\
\text { to disinfect the infected \& instrumented canal [52]. }\end{array}$ \\
\hline Dr. Alfred E. Gysi & 1865-1957 & $\begin{array}{l}\text { A famous clinician from Zurich SU who produced the } 1^{\text {st }} \text { hhoto of the pulp-dentine tissues \&who advanced } \\
\text { the concept of fluid flow of tooth dentinesensitivity [23]. }\end{array}$ \\
\hline Dr. W. H. G. Logan & $1872-1943$ & $\begin{array}{l}\text { Dean of Loyola who advocated for the advancement of US dental schools with research.He was responsible } \\
\text { to bring many Austrian dental researchers to the US in the 1940's. }\end{array}$ \\
\hline Dr. Charles F. Bödecker & $1895-1965$ & $\begin{array}{l}\text { A famous light microscopic histologist who wrote the } 1^{\text {st }} \text { US comprehensive dental text on the anatomy \& } \\
\text { physiology of human stages of tooth growth \& development as well as dentinogenesis. He is noted to have } \\
\text { surpassed all of his fellow contemporaries in creative research [26]. }\end{array}$ \\
\hline Dr. Baliant Orban & $1889-1960$ & $\begin{array}{l}\text { A famous notable to the US from Vienna who immigrated to the US in } 1940 \text {.He published an erudite } \\
\text { text on Periodontics as well as Oral Histology \& Embryology that are still relevant today as well as over } \\
\text { 50-significant research pulp biology publications [30]. }\end{array}$ \\
\hline Dr. Rudolf Kronfeld & $1901-1940$ & $\begin{array}{l}\text { A very famous dental notable who } 1^{\text {st }} \text { was a famous researcher \& then gained his DDS.He contributed } \\
\text { publications \& texts to the advancement of our profession. Sadly, he died at just at an age of } 39 \text { [31, 32]. }\end{array}$ \\
\hline Dr. Louis I. Grossman & 1902-1988 & $\begin{array}{l}\text { A forward thinking researcher \& endodontist who promoted the importance of differential diagnosis, } \\
\text { prognosis \&treatment of endodontic lesions. He isremembered as the father of US Endodontics. He published } \\
\text { a textbook ROOT CANAL THERAPY that defined the principles of diagnosis, prognosis \& treatment of } \\
\text { painful \& infected teeth }[40,55] \text {. }\end{array}$ \\
\hline Dr. Sol Bernick & 1915-1989 & $\begin{array}{l}\text { A famous LM \& TEM histologist who was } 1^{\text {st }} \text { to publish several papers on the transmission-ultramicroscopy } \\
\text { (TEM) of dentine \& the carious nature \& the specific changes during the } 4 \text {-stages of caries progression in } \\
\text { human teeth[36,37]. }\end{array}$ \\
\hline Dr. D. Pease \& Dr.R. Baker & 1948 & $\begin{array}{l}\text { They developed predictable fixation, processing, embedding \& sectioning of tissues for observation by } \\
\text { transmission electron ultramicroscopy [33]. }\end{array}$ \\
\hline Dr. Martin Brännström & 1922-2001 & $\begin{array}{l}\text { Dr. Brännström's research demonstrated that bacteria were responsible for pulp necrosis. He was the } 1^{\text {st }} \\
\text { toconfirm the hydrodynamic theory of tooth sensitivity in human teeth }[24,25] \text {. }\end{array}$ \\
\hline Dr. William (Bill) Cotton & Circa 1930-2005 & $\begin{array}{l}\text { He personally labored to organize the formation of the Pulp Biology Group in } 1972 \& \text { became its } 1^{\text {st }} \text { president. } \\
\text { He was also remembered to have supported Dr. Martin Brännström's concepts of hydrodynamics \& bacterial } \\
\text { microleakage causingrecurring infection\& being responsible for pulp infection underneath restorations. }\end{array}$ \\
\hline Dr. L. J. Baume & Geneva Switzerland & $\begin{array}{l}\text { Published a comprehensive monograph The Biology of Pulp \& Dentine: A Historic, Terminological- } \\
\text { Taxonomic, Histologic - Biochemical, Embryonic and Clinical Survey in } 1980 \text { [1]. }\end{array}$ \\
\hline $\begin{array}{l}\text { Drs. Brännström Garberoglio } \\
\text { Massler\& Kidd }\end{array}$ & 1969-1976. & $\begin{array}{l}\text { The pulp biologyresearch publications of these dental Notables demonstrated that microleakage of bacteria } \\
\text { into \& through the restoration interface was the primary cause of recurrent caries, pulp inflammation, } \\
\text { eventual necrosis \& recurring patient hypersensitivity to thermal extremes. }\end{array}$ \\
\hline
\end{tabular}

\section{References}

1. Baume LJ (1980) The biology of pulp and dentine: A historic, terminologicaltaxonomic, histologic - biochemical, embryonic and clinical survey. S. Karger Co. Pub. München-Paris-London-New York-Sydney. 1-246.

2. Witzel A (1879) Die antiseptische Behandlung der Pulpakrankheiten des Zahnes mit Beiträgen zur Lehre von den Neubildlung in der Pulpa. Ash \& Söhne, Berlin.

3. Lufkin A (1938) A history of dentistry illustrated with 90 engravings. Lea \& Febiger, Philadelphia PA, USA.

4. Grossman L (1950) History of root canal therapy, Chapter 1 - Root Canal Therapy, Philadelphia PA. Lea \& Febiger. 15-16.

5. Hunter J (1771) Treatise on the natural history and diseases of the human teeth, 1st edition, J. Johnson, London UK.
6. Hunters Works (1837) Palmer's edition, Published by Longman, Rees, Orme, Brown Green \& Longman. London. 4: 315-318.

7. Fauchard $\mathrm{P}$ (1746) Methods for removing decay and restoring teeth. Le chirurgiendentiste ou traité des dentes, Paris France. Mariett. vol I 456 \& vol II. 346.

8. Fauchard P (1728) Le chirurgien dentiste ou traite des Dents, The Surgeon Dentist Mariette, Paris.

9. Chareix F (2008) La Hire, Philippe de la. vol. 2, 662-664, in The Dictionary of SeventeenthCentury French Philosophers, edited by Luc Foisneau. London Continuum.

10. Hudson E (1824) (vide) Taylor J.A. History of Dentistry, Philadelphia Pa., Lea \& Febiger. 77-78.

11. Baume L (1980) The biology of pulp and dentine: a historic, terminological-taxonomic, histologic - biochemical, embryonic and clinical survey. S. Karger Co. Pub. MünchenParis-London-New York-Sydney. 
12. von Purkinje J (1834) Der microtuomische Quetscher, lin bei microscopischen Unterscheengen unentberlliches Instrument. Arch Anat Physiol University of Breslau 385-390.

13. Fraenkel M (1835) On the observations of the intrinsic structure of the human teeth. University of Breslau. Friedlander.

14. Raschkow I (1835) Meletemata circa mammalium dentium evolutionem. Diss Inaug Anatomico- Physiologica. Friedlaender, Vratislaviae.

15. Tomes $\mathbf{J}$ (1848) On the structure of the dental tissues in the order of Rhodntia. Phil Trans R Soc London. 140: 529-567.

16. von Kolliker R (1852) Handbuch der Gewebelehre des Menschen. Engelmann, Leipzig.

17. Harris C (1855) Filling teeth with crystalline and sponge gold. Harris' Principles \& Practice of Dental Surgery, 6th ed. No. 51. N. Charles St. Part-3, Chapt 7. 343.

18. Black G (1884) The formation of poisons by microorganisms: A biological study of the germ theory of disease, P. Blackiston, Son \& Co. 1-170.

19. Black G (1895) An investigation of the physical characters of the human teeth in relation to their diseases and to practical dental operations, together with the physical characters of the filling material. Dent Cosmos 37: 353-356.

20. Liebig J (1831) Ueber einen neuen Apparat zur Analyse organischer Körper, und über die Zusammensetzung einiger organischen Substanzen. Annalen der Physik 21: 1-47.

21. Clapp G (1925) The life and work of john leon williams. Dental Digest 220 W. 42nd St. New York, USA. 1-276.

22. Neill J (1842) Sensibility of the Teeth explained on Hydrostatic Principles. Univ. of Pennsylvania PA. Thesis: Later published in the Med Exam. $J \& A m ~ J ~ M e d ~ S c i$ (October 1850).

23. Gysi A (1900) An attempt to explain the sensitiveness of dentin. Br J Dent Sci 43: 865-868.

24. Brannstrom M (1963) Dentin sensitivity and aspiration of odontoblasts. J Am Dent Assoc 66: 366-370. [Crossref]

25. Brännström M (1963) A hydrodynamic mechanism in the transmission of painproduced stimuli through the dentin. In: Anderson DJ ed, Sensory Mechanisms in Dentine. New York, Pergamon Press.73-79.

26. Bödecker C (1879) On secondary dentine. Dental Cosmos 21: 353-416.

27. Kitasako Y, Shibata S, Cox CF, Tagami J (2002) Location, arrangement and possible function of interodontoblastic collagen fibres in association with calcium hydroxideinduced hard tissue bridges. Int Endod J 35: 996-1004. [Crossref]

28. Gies W (1926) Dental education in the United States and Canada. A report to the carnegie foundation for the advancement of teaching. Bulletin \#19.

29. Gottlieb B, Orban B, Diamond M (1938) Biology and pathology of the tooth and its supporting mechanism, The Macmillan Co., New York.

30. Orban B (1929) Oral histology and embryology, The P. Blakiston Son \& Co., Philadelphia. PA.

31. Kronfeld R (1933) Histopathology of the human teeth and their surrounding structures. Lea \& Febiger, Philadelphia, PA.

32. Kremenak NW, Squier CA (1997) Pioneers in oral biology: the migrations of gottlieb, kronfeld, orban, weinmann, and sicher from Vienna to America. Crit Rev Oral Bio Med 8: 108-128. [Crossref]

33. Pease D, Baker R (1948) Sectioning techniques of electron microscopy using a conventional microtome. Proc Soc Exp Biol \& Med 67: 470-474.
34. Gerould G (1944) Ultramicrostructures of the human tooth as revealed by the electron microscope. J Dent Res 23: 239.

35. Cox C (2017) Summer Sabbatical visits to the Univ. of Mich. Oral Histology research laboratory, 1970 through 1978. Personal communication.

36. Bernick S, Baker RF, Rutherford RL, Warren O (1952) Electron microscopy of enamel and dentin. J Am Dent Assoc 45: 689-696. [Crossref]

37. Bernick S, Warren O, Baker RF (1954) Electron microscopy of carious dentin. J Dent Res 33: 20-26. [Crossref]

38. Keep N of Boston MA (1876) (vide) Koch C.R.E. History of Dental Surgery, (1909) Chicago. National Art Publication Co., 209-212.

39. Johnson H (1928) of Atlanta GA, coined the term endodontics. vide James L. Gutmann History of Endodontics, In: Pathways of the Pulp. eds. Cohen S. \& Burns R.C. 4th ed. St. Louis. The C. V. Mosby Co.

40. Grossman L (1981) Endodontic practice, Philadelphia PA. Lea \& Febiger, 10:1-279.

41. Lambert S, Goodwin G (1929) Medical Leaders, Indianapolis. Bobbs-Merrill Co. 15 $\& 95$.

42. Editorial (1941) Paracelsus after 400 years. J Am Med Assoc 117: 1018.

43. Miller J (1934) The influence of claude bernard in experimental methods on medicine Proc Inst Med Chicago 10: 162-166.

44. Coolidge E (1950) Endodontia: The clinical pathology and treatment of the dental pulp and pulpless teeth. Lea \& Febiger. Therapeutic Principles. 149-156.

45. Coolidge E (1950) Endodontia: The clinical pathology and treatment of the dental pulp and pulpless teeth. Lea \& Febiger. Germicides for the treatment of infected root canals 157-162.

46. Jordan E (1933) Textbook of general bacteriology, 10th ed, W. B. Saunders Co., Philadelphia PA.

47. Prinz H (1926) Dental materia medica and therapeutics, 6th ed. C. V. Mosby Co. pp 29-33.

48. Appleton J (1933) Bacterial infection, 2nd ed, Lea \& Febiger Co. Philadelphia PA. 465.

49. Coolidge E (1950) Studies of germicides for the treatment of root canals. J Am Dent Assoc 16: 697-699.

50. Coolidge E (1928) Pulp pathology and treatment problems. J Am Dent Assoc 15: 1621 1625.

51. Feirer W, Leonard V (1927) Hexylresorcinol in oral antisepsis with special reference to solution S.T.37. Dental Cosmos 63: 881-883.

52. Walkoff O (1887) Die antiseptische Behandlung der Pulpakrankheiten des Zahnes mi Beitragen zur Lehre von denNeubildungen in der Pulpa, Berlin: Ash \& Sohne.

53. Pryde J (1926) Recent advances in biology and medicine. The Blakiston C., Philadelphia Pa. pp. 312-317.

54. Dakin H, Dunham E (1917) A handbook on antiseptics. The Macmillan Co. New York. 13-32.

55. Grossman L (1945) Treatment of pulpless teeth with a concentrated sulfonamide solution. J Am Dent Assoc 32: 1431-1435.

Copyright: (C2017 Cox CF. This is an open-access article distributed under the terms of the Creative Commons Attribution License, which permits unrestricted use, distribution, and reproduction in any medium, provided the original author and source are credited. 